\title{
Physiological features of Schizosaccharomyces pombe of interest in making of white wines
}

\author{
S. Benito $~ F$. Palomero $\cdot$ A. Morata $~$ \\ F. Calderón · D. Palmero · J. A. Suárez-Lepe
}

\begin{abstract}
This work studies the physiology of Schizosaccharomyces pombe strain 938 in the production of white wine with high malic acid levels as the sole fermentative yeast, as well as in mixed and sequential fermentations with Saccharomyces cerevisiae Cru Blanc. The induction of controlled maloalcoholic fermentation through the use of Schizosaccharomyces spp. is now being viewed with much interest. The acetic, malic and pyruvic acid concentrations, relative density and $\mathrm{pH}$ of the musts were measured over the entire fermentation period. In all fermentations in which Schizo. pombe 938 was involved, nearly all the malic acid was consumed and moderate acetic concentrations produced. The urea content and alcohol level of these wines were notably lower than in those made with Sacch. cerevisiae Cru Blanc alone. The pyruvic acid concentration was significantly higher in Schizo. pombe fermentations. The sensorial properties of the different final wines varied widely.
\end{abstract}

\section{Introduction}

The Schizosaccharomcyes genus possesses interesting metabolic properties that can be of use in white winemaking. However, Schizosaccharomcyes is not used due to certain off-flavours commonly associated with their metabolism. There is no doubt that they are commonly isolated from wines suffering from strong organoleptic and chemical deviations through the appearance of acetic acid, $\mathrm{H}_{2} \mathrm{~S}$, acetaldehyde, acetoin and ethyl acetate [1-3].

On the other hand, not only because these yeasts possess high fermentative power $[4,5]$ but also due to their capacity to metabolise malic acid, these yeasts are now being viewed with notable interest, especially for the elaboration of wines with high acidity levels from northern Spanish wine-growing regions such as Galicia, the Basque Country, Rioja and Navarra. Under these conditions where growth cycles are short, grapes accumulate excessively high quantities of malic acid, and its elimination is particularly necessary.

Until now, the lactic acid bacteria Oenococcus oeni and Lactobacillus plantarum have been the most traditionally used organisms to remove malic acid from musts and wines especially in red winemaking $[6,7]$. However, the malolactic fermentation performed by these microorganisms is one of the most complicated processes in enology due to growing requirements [8].

White young wines are usually produced without induction of malolactic fermentation in order to preserve young aroma characteristics. But under the aforementioned 
climatic conditions, total or partial demalication through the induction of Schizosaccharomyces spp. could be highly recommendable. Maloalcoholic fermentation could preserve young aroma characteristics and, at the same, reduce the 'green apple sourness' that malic acid brings to wine when it is present in high levels. Furthermore, Schizosaccharomcyes pombe and Schizosaccharomcyes malidevorans readily grow in musts and wines, rendering the use of lactic acid bacteria unnecessary, maintaining grape variety and yeast fermentation aromas.

Different research lines have also been developed to solve problems in this regard linked to the genetic modification of fermentative Saccharomyces spp. by integrating Oenococcus oeni malolactic enzyme gene (mleA) that makes them capable of decarboxylating malate to lactate [9-12]. Regardless of the controversy over genetically modified organisms (GMO), their use at industrial level is restricted by European legislation (EC Regulation $N^{\circ} 479 / 2008$ ) and subjected to numerous controls concerning the 'substantial equivalence' between a conventional product and a transgenic one.

Schizosaccharomyces spp. shows a stronger autolytic release of parietal polysaccharides than the one showed by Sacch. cerevisiae, due to their particular cell wall formation; this could be of interest in white wines aged over lees [13].

Other recent findings also suggest that Schizosaccharomyces spp. possesses urease activity [14] that can be used in order to reduce the urea content during fermentation processes [15]. This compound is the main precursor of ethyl carbamate (a toxic compound) in wine [16].

Taking into account the above, in wine production the presence of some non-Saccharomyces yeasts, such us Schizosaccharomyces spp., causes considerable interest [1, 17-20]. Schizosaccharomyces spp. could be used and immobilised in alginate [17,21-23] or in mixed and sequential fermentations with Saccharomyces spp. [20] to soften its occasional negative sensorial impacts [24]. These fermentation technologies have presented significant results in the deacidification of wine on a laboratory scale [21, 25].

The use of Schizosaccharomyces spp. alone, or with other yeast species in combined fermentations, could reduce wine standardisation as described by some authors $[18,26,27]$, increasing the complexity and aroma profile of modern wines [28]. Contradictory results have been obtained in various studies that examined the impact of Schizosaccharomyces spp. on sensorial analysis and volatile compound composition [25, 29-31]. For example, this genus has been related to high levels of ethyl acetate, acetaldehyde [30] or acetic acid [15, 31]. However, wines produced in partial fermentations with Saccharomyces spp. have been judged of better quality than wines fermented only with this genus [29]. Furthermore, use of a Schizosaccharomyces malidevorans mutant strain produced wines that lacked obvious organoleptic defects [25].
This study examines the potential of the metabolism of Schizosaccharomyces pombe 938 applied to white wines with high malic acid levels.

\section{Materials and methods}

\section{Microorganisms}

The yeast strains used in this study were Schizo. pombe 938 from the Instituto de Fermentaciones Industriales collection (IFI, CSIC, Madrid, Spain) and Saccharomyces cerevisiae Cru Blanc (Maurivin, Melbourne, Australia).

\section{Fermentations}

All fermentations were prepared using the must from Vitis vinifera L.cv. Airen grapes grown in San Martín de Valdeiglesias (Madrid, Spain). Using a method similar to that described by [32], 3.5 $\mathrm{L}$ of unpasteurised must was placed in 4.9-L glass fermentation vessels, leaving enough space for carbon dioxide emission. Sulphur dioxide $(60 \mathrm{mg} / \mathrm{L})$ (Panreac, Barcelona, Spain) was added to each, along with $3 \mathrm{~g} / \mathrm{L}$ malic acid (Panreac, Barcelona, Spain), ensuring at a final concentration of $5 \mathrm{~g} / \mathrm{L}$. The sugar content was '226' $\mathrm{g} / \mathrm{L}$, relative density 1096 at $15^{\circ} \mathrm{C}$ and $\mathrm{pH} 3.1$.

Four assays were performed (all in triplicate): 1) inoculation of the must with solely Schizo. pombe 938, 2) inoculation of the must with solely Sacch. cerevisiae Cru Blanc, 3) inoculation of the must with Schizo. pombe 938 and Sacch. cerevisiae Cru Blanc (mixed fermentation) and 4) inoculation of the must with Schizo. pombe 938 followed by Sacch. cerevisiae Cru Blanc 48 h later. Schizo. pombe 938 for these inoculations involved the use of $50 \mathrm{~mL}$ of this culture that was grown in sterile must until it reached a population of $10^{6}$ cfu/mL; all $25 \mathrm{~g} / \mathrm{HL}$ Saccharomyces cerevisiae Cru Blanc was added to all fermentations in which this yeast was involved, following the manufacturer's recommendations.

All fermentation processes were carried out at $25^{\circ} \mathrm{C}$. Once fermentation of sugars was complete (deemed to be represented by a remaining glucose + fructose concentration of $<2 \mathrm{~g} / \mathrm{L}$ ), the wines were racked and stabilised during 7 days at $4{ }^{\circ} \mathrm{C}$ and the final product was bottled. Corked bottles were placed horizontally in a climate chamber TR2V120 (La Sommelière, Saint-Saturnin, France) with conditions of constant temperature and humidity $\left(18^{\circ} \mathrm{C}\right.$ and $70 \%$ relative humidity). These conditions were maintained for 1 month until the sensory evaluation took place.

Analytical determination: non-volatile compounds

Glucose + fructose, malic acid, lactic acid, acetic acid, glycerol, citric acid, primary amino nitrogen, urea and 
pyruvic acid were all determined using a Y15 Enzymatic Autoanalyzer (Biosystems, Barcelona, Spain). These analyses were performed using the appropriate Biosystems kits (http://www.biosystems.es), except for the pyruvic acid, which was determined using a kit from Megazyme (Bry, Ireland).

$\mathrm{pH}$, dry extract, total acidity, alcohol content and relative density were determined following the methods set out in the Compendium of International Methods of Analysis of Wines and Musts [33].

Analytical determinations: volatile compounds

The changes in the concentration of 18 volatile compounds (acetaldehyde, methanol, n-propanol, diacetyl, ethyl acetate, isobutanol, $n$-butanol, 2-butanol, amylic alcohol, isoamylic alcohol, isobutyl acetate, ethyl butyrate, ethyl lactate, $n$-hexanol, isoamyl acetate, 2-phenylethyl alcohol, 2-phenylethyl acetate and 2,3-butanediol), all of which influence wine quality, were monitored by gas chromatography using an Agilent Technologies 6850 gas chromatograph with a flame ionisation detector (Hewlett Packard, Palo Alto, CA, USA). The apparatus was calibrated with a 4-methyl-2-pentanol internal standard. Gas chromatography quality compounds (Fluka, SigmaAldrich Corp., Buchs SG, Switzerland) were used to provide standard patterns. Higher alcohols were separated as described in the Official Methods for the Analysis of Musts and Wines [33]. The detection limit was $0.1 \mathrm{mg} / \mathrm{l}$.

\section{Sensorial analysis}

The final wines were assessed (blind) by a panel of 10 experienced wine tasters, all members of the staff of the Food Technology Department at the Universidad Politécnica de Madrid. Assessment took place in standard sensory analysis chambers with separate booths. Prior to the creation of a consistent terminology by consensus, two visual descriptors, five aromas and four taste attributes were chosen to describe the wines. Formal assessment consisted of two sessions held on different days. The panellists used a $10-\mathrm{cm}$ unstructured scale, from 0 (no defect) to 100 (very strong perceptible defect), to rate the intensity of 12 attributes (Fig. 4).

\section{Statistical analysis}

Means and standard deviations were calculated and ANOVA performed using PC Statgraphics v.5 software (Graphics Software Systems, Rockville, MD, USA). Significance was set at $p<0.05$ for the ANOVA matrix $F$ value. The multiple range test was used to compare means.

\section{Results and discussion}

\section{Fermentative kinetics}

Figure 1 shows the fermentation kinetics and variations in different variables. Figure 1a shows the change in the relative density during the fermentation period. All fermentation kinetics finished properly, and all ended around day 10. All wines presented a residual sugar concentration of $<1.5 \mathrm{~g} / \mathrm{L}$ (Table 1) and with relative densities around 990 at $20^{\circ} \mathrm{C}$ (Fig. 1a). The data show that Schizo. pombe, whether alone or combined, were able to consume sugars similar to Sacch. cerevisiae alone. Schizosaccharomyces spp. has been described as a high fermentative power yeast [5], although in certain assays they showed slower fermentation kinetics [15].

\section{Biological deacidification of wine}

Figure $1 \mathrm{~b}, \mathrm{c}$ and $\mathbf{d}$ shows the changes of acetic and malic acid contents and $\mathrm{pH}$ in the must. Fermentations with Sacch. cerevisiae Cru Blanc alone showed a reduction in malic acid of $19.40 \%$, to reach a final concentration of $4.02 \mathrm{~g} / \mathrm{L}$. These data agree with that reported by other authors [5, 15, 34-37] who report that malic acid can be metabolised by species other than Schizosaccharomyces although they only reduce its presence by some $25 \%$. In fermentations involving Schizo. pombe 938, nearly all the malic acid was consumed (Fig. 1b). This also agrees with other authors who recorded $75-100 \%$ reductions in malic acid by Schizosaccharomyces spp. [17, 21, 25, 29, 38-40]. This reduction largely occurred over the first $4-5$ days of fermentation. The final malic acid concentrations recorded were $0.04,0.04$ and $0.06 \mathrm{~g} / \mathrm{L}$ for only Schizo. pombe 938, in the sequential fermentations and mixed fermentation, respectively. There was a malic acid deacidification of around $99 \%$, with this reduction evident in the $\mathrm{pH}$ (Fig. 1c). A twofold decrease in total acidity value in the wines fermented with Schizo. pombe 938 was observed compared to the samples fermented with Sacch. cerevisiae Cru Blanc alone (Table 1). No significant differences were seen in terms of the malic acid concentration at the end of alcoholic fermentation in any of the assays involving Schizo. pombe 938, which showed a $\mathrm{pH}$ increase of 0.38-0.40 compared to the purely Sacch. cerevisiae Crue Blanc fermentations. Therefore, the interest in Schizosaccharomyces spp. as biological deacidifiers is proved in this study.

Schizosaccharomyces spp. is usually related to high productions of acetic acid in fermentations at laboratory scale [15]. This is its major drawback at least for the unselected strains commonly used in wine research. However, some authors report satisfactory results for 

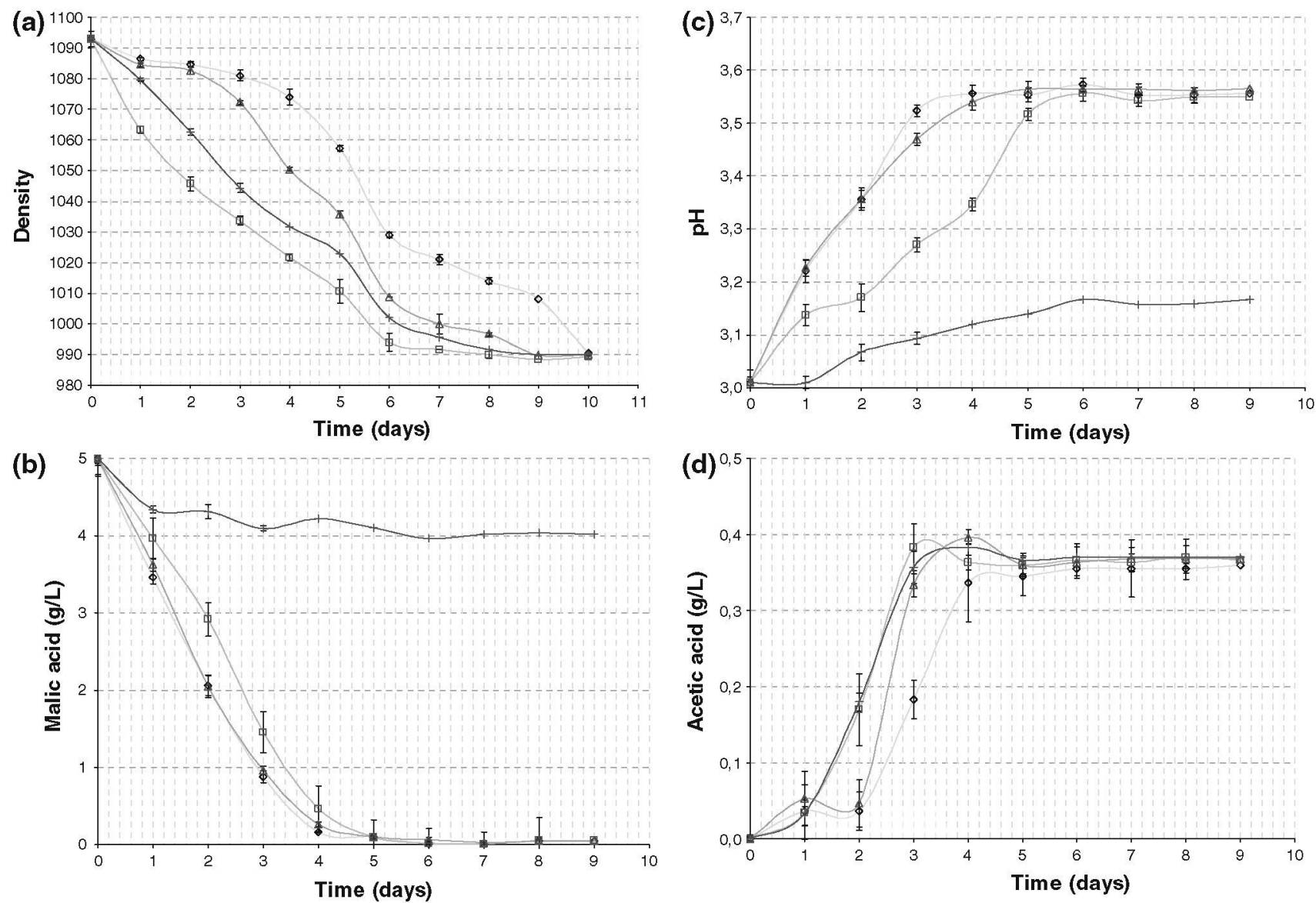

$$
\begin{array}{llll}
\hline \diamond 938 \quad \square-938+\mathrm{CB} \quad \triangle \quad 938 \ldots \mathrm{CB} \quad \text { + } \mathrm{CB} \\
\hline
\end{array}
$$

Fig. 1 a Change in relative density. b Consumption of malic acid. c Change in $\mathrm{pH}$. d Acetic acid production. Points are mean \pm standard deviation. Legend. $938=$ fermentation with Schizo. pombe 938 alone; $938+\mathrm{CB}=$ fermentation with Schizo. pombe $938+$ Sacch .

combined fermentations with other yeasts such as Saccharomyces ssp., obtaining wines with no olfactory defects $[21,25]$. In this study, the acetic acid concentration stabilised on the third to fourth day of fermentation. The acetic acid content remained at around $0.37 \mathrm{~g} / \mathrm{L}$ in all Schizo. pombe 938 fermentations (Fig. 1d). The selection of Schizosaccharomyces strains with low production of acetic acid could bring a new oenological tool for unbalanced musts. This may help remove the spoilage stigma attached to this species.

\section{Fermentation products}

Figure 2 shows the pyruvic acid concentration evolution over fermentation. The maximum concentration was reached on the second day in all fermentations, followed by a progressive reduction. The maximum values reached by Schizo. pombe 938 alone, in sequential fermentations with cerevisiae CB (i.e. mixed fermentation); $938 \ldots \mathrm{CB}=$ fermentation with Schizo. pombe 938 followed by Sacch. cerevisiae CB (i.e. sequential fermentation); $\mathrm{CB}=$ fermentation with Sacch. cerevisiae $\mathrm{CB}$ alone

Sacch. cerevisiae Cru Blanc, in mixed fermentations and with Sacch. cerevisiae Crue Blanc alone were 0.33, 0.28, 0.16 and $0.11 \mathrm{~g} / \mathrm{L}$, respectively. Other studies involving Schizosaccharomyces strain fermentations in pasteurised media, values up to $0.39 \mathrm{~g} / \mathrm{L}$, were recorded [15]. The pyruvic acid levels in fermentations involving Schizo. pombe were always over $0.16 \mathrm{~g} / \mathrm{L}$. These values are high compared to others recorded in previous studies for selected Sacch. cerevisiae strains and nowadays used in winemaking due to their special ability to produce high levels of pyruvic acid, but in this case only a maximum pyruvic acid value of $0.13 \mathrm{~g} / \mathrm{L}$ was reached [41]. NonSaccharomyces yeast with high pyruvate production might therefore be of interest in terms of pigment production and stability, especially in red wines [8]. These data could also help to explain their higher glyceropyruvic pathway, as described by other authors during the first stages of the alcoholic fermentation [5]. 


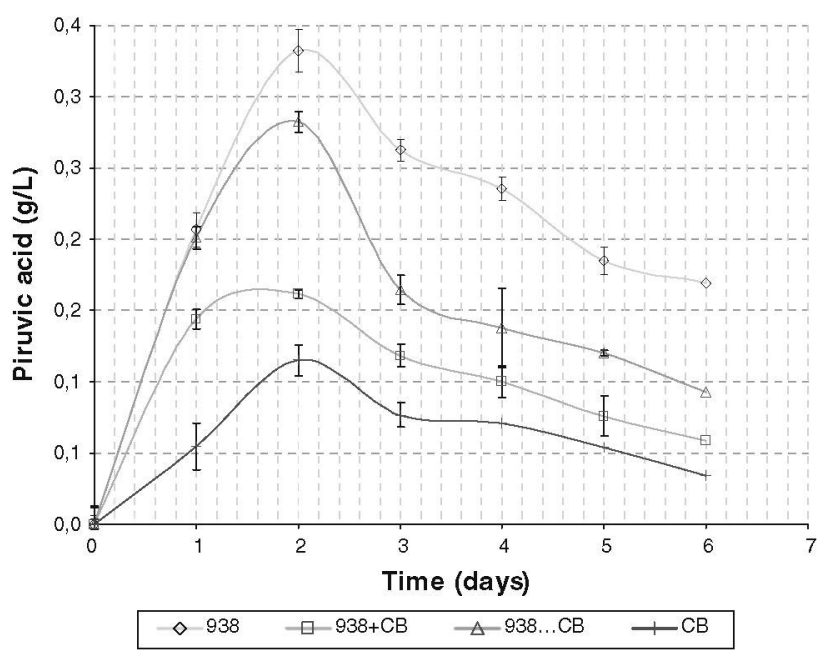

Fig. 2 Pyruvic acid production. Points are mean \pm standard deviation. Legend as for Fig. 1

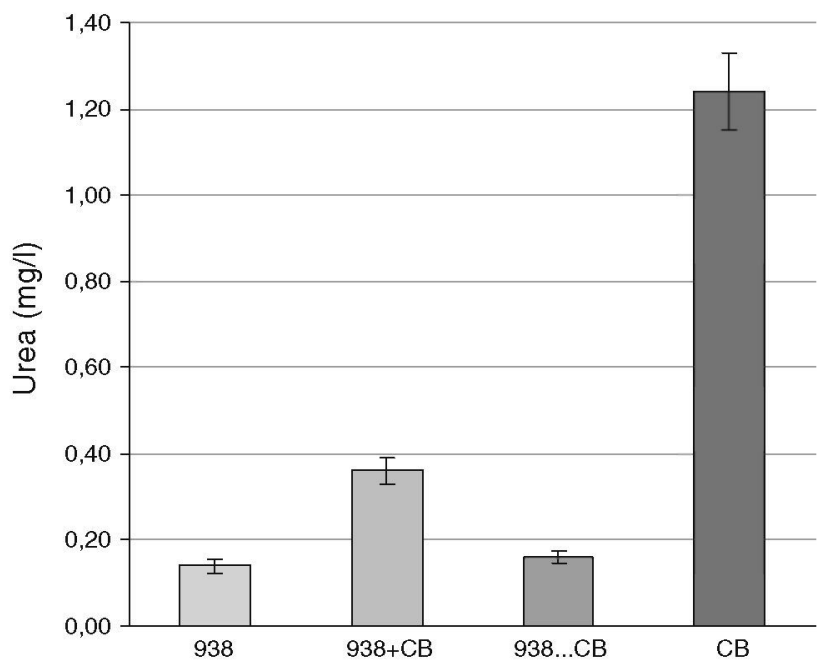

Fig. 3 Urea concentration (mean \pm standard deviation) of the final wines. Legend as for Fig. 1

The urea content of the finished wines (Fig. 3) was $0.14 \mathrm{mg} / \mathrm{L}$ for that made with only Schizo. pombe 938, $0.16 \mathrm{mg} / \mathrm{L}$ for that made with the sequential fermentation, $0.36 \mathrm{mg} / \mathrm{L}$ for that made with the mixed fermentation and $1.22 \mathrm{mg} / \mathrm{L}$ for that made with $S$. cerevisiae Cru Blanc alone. The differences between the fermentations were significant $(p<0.05)$ (Table 1). These differences can be easily explained due to the urease activity of Schizo. pombe [14]. A reduction in urea generally leads to lower ethyl carbamate (toxic compound) content because it is its main precursor [42]; the use of Schizo. pombe 938 could, therefore, improve wine safety from a toxicological point of view. This strain may also be of interest as it would reduce the possibility of lactic acid bacteria growing by removing malic acid (another of nutrient source), thus reducing the risk of biogenic amine formation $[40,43,44]$. 
The glycerol content of the wines fermented with Schizo. pombe 938 was higher than those recorded in the wine produced with Saccharomyces cerevisiae Cru Blanc. These differences were statistically significant $(p<0.05)$ and are in line with other results which show a highly developed glyceropyruvic pathway for Schizo. pombe, possibly explaining its greater production of pyruvic acid and glycerine compared to other yeasts [5].

The final alcohol content of the wines made in fermentations involving Schizo. pombe 938 was lower than those fermented by Sacch. cerevisiae Cru Blanc alone (Table 1). This confirms the findings of other researches who reported that Schizo. pombe was a relatively poor producer of alcohol from sugar [45]. The sugar consumption could also be used to produce compounds other than ethanol or to increase the yeast biomass.

\section{Volatile compounds}

Table 2 shows production of volatile compounds in the different fermentations. Significant differences were seen in acetaldehyde production. Higher amounts of this compound were recorded in the wines fermented with Schizo. Pombe 938, both alone or combined with Saccharomyces, than those fermented with Saccharomyces Cru Blanc alone. Methanol production (36-40 $\mathrm{mg} / \mathrm{L}$ ) never exceeded the legal limit for white wines [46]. At the end of fermentation, no significant differences were shown in terms of ethyl acetate concentration. These values were $<70 \mathrm{mg} / \mathrm{L}$ and can therefore be considered to be acceptable [47]. Higher alcohols (2-methyl-1-butanol and 3-methyl-1-butanol) were produced in moderate quantities in all fermentations, although significantly higher values were reached when Sacch. cerevisiae Crue Blanc was involved. The formation of 2-phenylethanol was moderate, although slightly more was obtained in the fermentation which only involved Sacch. cerevisiae Cru Blanc, a factor which may have increased its 'floral' aroma. However, there were no significant differences between the mixed inoculations in 2-phenylethanol contents. Significantly more isoamyl acetate was produced in the fermentation involving Sacch. cerevisiae Cru Blanc alone. Ethyl lactate production ranged from 6.86 to $17.75 \mathrm{mg} / \mathrm{L}$, recording the highest value when Schizo. pombe 938 was used alone.

\section{Sensorial evaluation}

Figure 4 shows 'spider web' diagram for the average scores of 12 aromas and taste attributes. Fermentation with Sacch cerevisiae Cru Blanc alone produced the strongest sensations of acidity. This is directly correlated with the final levels of total acidity and malic acid described in Table 1. No differences were found between the tasters regarding oxidation, reduction, acetic acidity and hue.

Table 2 Volatile compounds (mg/L) detected in the different fermentations involving the use of Schizosaccharomyces pombe 938 and Saccharomyces cerevisiae Cru Blanc (CB) alone or combined (all performed at $25^{\circ} \mathrm{C}$ with an initial sugar concentration of $226 \mathrm{~g} / \mathrm{L}$ and initial malic acid content of $5 \mathrm{~g} / \mathrm{L}$ )

\begin{tabular}{lllll}
\hline Compounds & $\begin{array}{l}\text { Schizo. } \\
\text { pombe } 938\end{array}$ & $\begin{array}{l}\text { Schizo. pombe } 938+ \\
\text { Sacch. cerevisiae CB }\end{array}$ & $\begin{array}{l}\text { Schizo. pombe 938 followed } \\
\text { by Sacch. cerevisiae CB }\end{array}$ & $\begin{array}{l}\text { Sacch. cerevisiae } \text { CB } \\
\text { Acetaldehyde }\end{array}$ \\
Methanol & $27.10 \pm 2.39 \mathrm{~b}$ & $23.22 \pm 2.18 \mathrm{~b}$ & $26.21 \pm 2.48 \mathrm{~b}$ & $16.21 \pm 1.26 \mathrm{a}$ \\
1-Propanol & $36.59 \pm 1.09 \mathrm{a}$ & $44.42 \pm 8.639 \mathrm{a}$ & $43.91 \pm 7.43 \mathrm{a}$ & $40.01 \pm 6.80 \mathrm{a}$ \\
Diacetyl & $20.91 \pm 0.85 \mathrm{ab}$ & $22.35 \pm 0.61 \mathrm{~b}$ & $22.18 \pm 1.79 \mathrm{~b}$ & $19.61 \pm 0.95 \mathrm{a}$ \\
Ethyl acetate & $5.40 \pm 1.40 \mathrm{~b}$ & $2.12 \pm 1.34 \mathrm{a}$ & $2.56 \pm 1.03 \mathrm{a}$ & $2.12 \pm 0.12 \mathrm{a}$ \\
2-Butanol & $29.88 \pm 3.35 \mathrm{a}$ & $29.25 \pm 1.90 \mathrm{a}$ & $30.23 \pm 3.54 \mathrm{a}$ & $27.11 \pm 0.95 \mathrm{a}$ \\
Isobutanol & $\mathrm{nd}$ & $\mathrm{nd}$ & $\mathrm{nd}$ & $\mathrm{nd}$ \\
1-Butanol & $21.30 \pm 0.47 \mathrm{a}$ & $35.93 \pm 1.63 \mathrm{a}$ & $31.87 \pm 2.71 \mathrm{a}$ & $38.38 \pm 1.65 \mathrm{a}$ \\
2-Methyl-1-butanol & $70.45 \pm 3.75 \mathrm{a}$ & $98.77 \pm 6.72 \mathrm{c}$ & $\mathrm{nd}$ & $\mathrm{nd}$ \\
3-Methyl-1-butanol & $26.60 \pm 4.72 \mathrm{a}$ & $37.03 \pm 5.78 \mathrm{~b}$ & $33.96 \pm 1.23 \mathrm{ab}$ & $109.92 \pm 5.24 \mathrm{c}$ \\
Isobutyl acetate & $\mathrm{nd}$ & $\mathrm{nd}$ & $\mathrm{nd}$ & $35.90 \pm 5.07 \mathrm{~b}$ \\
Ethyl butyrate & $\mathrm{nd}$ & $\mathrm{nd}$ & $\mathrm{nd}$ & $\mathrm{nd}$ \\
Ethyl lactate & $17.75 \pm 1.98 \mathrm{c}$ & $8.83 \pm 0.17 \mathrm{ab}$ & $12.86 \pm 0.48 \mathrm{~b}$ & $\mathrm{nd}$ \\
2-3 Butanediol & $853.02 \pm 38.80 \mathrm{~b}$ & $779.36 \pm 36.28 \mathrm{~b}$ & $810.18 \pm 29.78 \mathrm{~b}$ & $6.86 \pm 0.05 \mathrm{a}$ \\
Isoamyl acetate & $3.50 \pm 0.30 \mathrm{a}$ & $3.63 \pm 0.39 \mathrm{ab}$ & $3.51 \pm 0.38 \mathrm{a}$ & $517.9 \pm 24.04 \mathrm{a}$ \\
Hexanol & $4.12 \pm 0.07 \mathrm{a}$ & $4.552 \pm 0.13 \mathrm{~b}$ & $4.397 \pm 0.10 \mathrm{~b}$ & $4.47 \pm 0.76 \mathrm{~b}$ \\
2-Phenylethanol & $30.58 \pm 7.92 \mathrm{a}$ & $46.71 \pm 2.77 \mathrm{bc}$ & $42.23 \pm 2.26 \mathrm{~b}$ & $4.480 \pm 0.08 \mathrm{~b}$ \\
Phenylethyl acetate & $5.25 \pm 0.20 \mathrm{a}$ & $5.97 \pm 0.12 \mathrm{~b}$ & $5.93 \pm 0.12 \mathrm{~b}$ & $52.54 \pm 5.95 \mathrm{c}$ \\
\hline Re & & $5.99 \pm 0.13 \mathrm{~b}$ &
\end{tabular}

Results represent the mean \pm SD for three replicates. Means in the same row with the same letter are not significantly different $(p<0.05)$ 
Fig. 4 Taste and aroma attribute scores for the final wines produced in the different fermentations involving the use of Schizosaccharomyces pombe 938 and Saccharomyces Cerevisiae Cru Blanc (CB) alone or combined (all performed at $25^{\circ} \mathrm{C}$ with an initial sugar concentration of $226 \mathrm{~g} / \mathrm{L}$ and initial malic acid content of $5 \mathrm{~g} / \mathrm{L}$ )... Legend $938=$ fermentation with Schizo. pombe 938 alone; $938+\mathrm{CB}=$ fermentation with Schizo. pombe $938+$ Sacch . cerevisiae $\mathrm{CB}$ (i.e. mixed fermentation); $938 \ldots$

$\mathrm{CB}=$ fermentation with Schizo pombe 938 followed by Sacch. cerevisiae $\mathrm{CB}$ (i.e. sequential fermentation);

$\mathrm{CB}=$ fermentation with Sacch cerevisiae $\mathrm{CB}$ alone

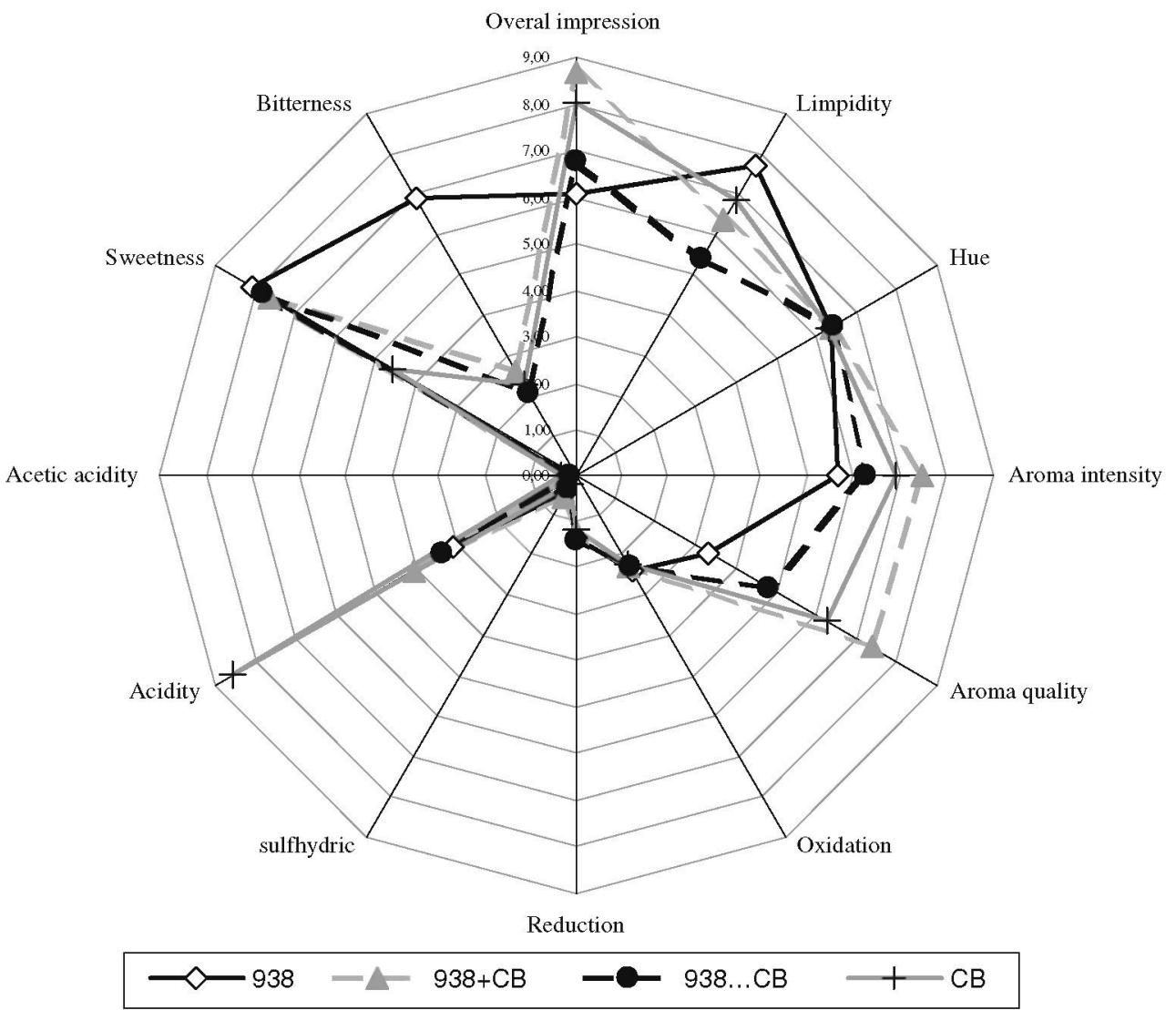

None of the wines that involved fermentation with Schizo. pombe 938 had any perceptible organoleptic problems, although a sensation of bitterness was higher in the case of fermentation with Schizo. pombe 938 alone. The mixed fermentation received the best scores from all tasters followed by fermentation with Sacch. cerevisiae Cru Blanc alone.

\section{Conclusions}

This study shows that Schizo. pombe 938 meets the basic requirements for a white winemaking yeast that can be applied as a resource to solve technical problems, especially in musts with high malic acid content. The major drawback of this genus, strong acetic acid production, was solved in this study due to its correct management in mixed and sequential fermentation between Saccharomyces cerevisiae and Schizosaccharomyces pombe that minimised the level of volatile acidity. Other strains could be studied to see which might be selected in terms of their ability for malic deacidification, acetic acid production, pyruvic acid production, their volatile compound profile and lower amounts of urea production. Schizosaccharomyces spp. appears to be an alternative to be used in combination with
Saccharomyces cerevisiae in order to produce less standardised wines for the market.

The high pyruvic acid production of yeast strains such us Schizossaccharomyces pombe 938 could improve the formation of stable pigments in red wines. Finally, yeast strains with high urease activity can be used as a new tool to assure wine safety due to the breakdown of ethyl carbamate precursors.

Acknowledgments This study was funded by the Spanish Ministry of Science and Innovation (MCeI) (Project AGL2008-05603-C02-01/ AGR). The authors are very grateful for the help received from Biosystems S.A. Special thanks to Pablo Rodríguez Plaza for the donation of the enzyme kits used in this work.

\section{References}

1. Gallander JF (1977) Deacidification of eastern table wines with Schizosaccharomyces pombe. Am J Enol Vitic 28:65-72

2. Pitt JI, Hocking AD (1999) Fungi and food spoilage. An Aspen Publication, Gaithersburg, pp 459-460

3. Yokotsuka K, Otaki A, Naitoh H (1993) Controlled simultaneous deacidification and alcohol fermentation of a high-acid grape must using two immobilized yeasts, Schizosaccharomyces pombe and Saccharomyces cerevisiae. Am J Enol Vitic 44:371-377

4. Peynaud E, Sudraud P (1962) Utilisation de l'effet dèsacidifiant des Schizosaccharomyces en vinification de raisins acides. Technol Agric 13:309-328 
5. Suárez-Lepe JA, Leal I (2004) Microbiología enológica: fundamentos de vinificación, 3rd edn. Mundi-Prensa, Madrid, pp 346-355

6. Wibowo D, Eschenbruch R, Davis CR, Fleet GH, Lee TH (1985) Occurrence and growth of lactic bacteria in wine. Am J Enol Vitic 36:302-313

7. Henick-Kling T (1993) In: Fleet GH (ed) Wine microbiology and biotechnology. Harwood Academic Publishers, Switzerland, pp 289-326

8. Suárez-Lepe JA, Palomero F, Benito S, Calderón F, Morata A (2012) Oenological versatility of Schizosaccharomyces spp. Eur Food Res Technol. doi:10.1007/s00217-012-1785-9

9. Pretorius IS, Bauer FF (2002) Meeting the consumer challenge through genetically customized wine-yeast strains. Trends Biotechnol 20:426-432

10. Husnik JL, Volschenk H, Bauer J (2006) Metabolic engineering of malolactic wine yeast. Metabol Eng 8:315-323

11. Husnik JL, Delaquis PJ, Cliff MA (2007) Functional analyses of the malolactic wine yeast ML01. Am J Enol Vitic 58:42-52

12. Liu YL, Li H (2009) Integrated expression of the Oenococcus oeni mleA gene in Saccharomyces cerevisiae. Agric Sci China 8:821-827

13. Palomero F, Morata A, Benito S, Calderón F, Suárez-Lepe JA (2009) New genera of yeasts for over-lees aging of red wine. Food Chem 112:432-441

14. Deák T (2008) Handbook of food spoilage yeasts, 2nd edn. CRC Press. Taylor and Francis Group, Boca Raton, pp 294-297

15. Benito S, Palomero P, Morata A, Calderón F, Suárez-Lépe JA (2012) New applications for Schizosaccharomyces pombe in the alcoholic fermentation of red wines. Int $\mathbf{J}$ Food Sci Technol. doi: 10.1111/j.1365-2621.2012.03076.x

16. Uthurry C, Varela F, Colomo B, Suárez-Lepe JA, Lombardero J, García del Hierro JR (2004) Ethyl carbamate concentrations of typical Spanish red wines. Food Chem 88:329-336

17. Magyar I, Panik I (1989) Biological deacidification of wine with Schizosaccharomyces pombe entrapped in ca-alginate gel. Am J Enol Vitic 40:233-240

18. Fleet GH (2008) Wine yeasts for the future. FEMS Yeast Res 8:979-995

19. Kim DH, Hong YA, Park HD (2008) Co-fermentation of grape must by Issatchenkia orientalis and Saccharomyces cerevisiae reduces the malic acid content in wine. Biotech Lett 30:1633-1638

20. Kunicka-Styczynska A (2009) Glucose, L-Malic acid and $\mathrm{pH}$ effect on fermentation products in biological deacidification. Czech J Food Sci 27:319-322

21. Silva S, Ramon Portugal F, Andrade P, Texera M, Strehaino P (2003) Malic acid consumption by dry immobilized cells of Schizosaccharomyces pombe. Am J Enol Vitic 54:50-55

22. Rossini G (1993) Influence of sugar type and level on malate metabolism of immobilized Schizosaccharomyces pombe cells. Am J Enol Vitic 44:113-117

23. López-Toledano A, Mérida J, Medina M (2007) Colour correction in white wines by use of immobilized yeast on kappa-carragenate and alginate gels. Eur Food Res Technol 225:879-885

24. Unterholzner O, Aurich M, Platter K (1988) Geschmacks und Geruchsfehler bei Rotweinen verursacht durch Schizosaccharomyces pombe L. Mitteilungen Klosterneuburg, Rebe und Wein, Obstbau und Früchteverwertung 38:66-70

25. Thornton RJ, Rodríguez SB (1996) Deacidification of red and white wines by a mutant of Schizosaccharomyces malidevorans under commercial winemaking conditions. Food Microbiol 13:475-482

26. Bely M, Stoeckle P, Masneuf-Pomarede I, Dubourdieu D (2008) Impact of mixed Torulaspora delbrueckii-Saccharomyces cerevisiae culture on high sugar fermentation. Int J Food Microbiol $122: 312-320$

27. Anfang N, Brajkovich M, Goddard MR (2009) Co-fermentation with Pichia kluyveri increases varietal thiol concentrations in Savignon Blanc. Aust J Grape Wine Res 15:1-8
28. Ciani M, Comitini F, Mannazzu I, Domizio P (2010) Controlled and mixed culture fermentation: a new perspective on the use of non-Saccharomyces yeasts in winemaking. FEMS Yeast Res $10: 123-133$

29. Snow PG, Gallander JF (1979) Deacidification of white table wines trough partial fermentation with Schizosaccharomyces pombe. Am J Enol Vitic 30:45-48

30. Dharmadhikari MR, Wilker KL (1998) Deacidification of high malate must with Schizosaccharomyces pombe. Am J Enol Vitic 49:408-412

31. Sousa MJ, Mota M, Leâo C (1995) Effects of ethanol and acetic acid on the transport of malic acid and glucose in the yeast Schizosaccharomyces pombe: implications in wine deacidification. FEMS Microbiol Lett 126:197-202

32. Sampaio TL, Kennedy A, Vasconcelos MC (2007) Use of microscale fermentations in grape and wine research. Am J Enol Vitic 58(4):534-539

33. OIV (2012) Official methods for the analysis of musts and wines of the international organisation of vine and wine (OIV). Methods of analysis of wines and musts. (OIV-MA-INT-00-2012) http://www.oiv.int/oiv/info/enmethodesinternationalesvin

34. Côrte-Real M, Leaô C, Van Uden N (1989) Transport of L-malic acid and other dicarboxylic acids in the yeast Candida sphaerica. Appl Microbiol Biotech 31:551-555

35. Côrte-Real M, Leâo C (1990) Transport of malic acid and other dicarboxylic acids in the yeast Hansenula anomala. Appl Environ Microbiol 56:1109-1113

36. Rodriguez SB, Thornton RJ (1990) Factors influencing the utilisation of L-malate by yeasts. FEMS Microbiol Lett 72:17-22

37. Redzepovic S, Orlic S, Majdak A, Kozima B, Volschenk H, Viljoen-Bloom M (2003) Differential malic acid degradation by selected strains of Saccharomyces during alcoholic fermentation. Int J Food Microbiol 83:49-61

38. Taillandier P, Gilis M, Strehaino P (1995) Deacidification by Schizosaccharomyces: interactions with Saccharomyces. J Biotechnol 40:199-205

39. Gao C, Fleet GH (1995) Degradation of malic and tartaric acids by high density cell suspensions of wine yeasts. Food Microbiol 12:65-71

40. De Fátima M, Centeno F, Palacios A (2007) Desacidificación Biológica de mosto a través de la inoculación de levadura Schizosaccharomyces pombe encapsulada como alternativa a la no producción de aminas biógenas. In: International symposium of microbiology and food safety in wine "Microsafetywine". Villafranca del Penedés, Spain 20-21 November 2007

41. Morata A, Gómez-Cordovés MC, Colomo B, Suárez JA (2003) Pyruvic acid and acetaldehyde production by different strains of Saccharomyces cerevisiae: relationship with vitisin A and B formation in red wines. J Agric Food Chem 51:7402-7409

42. Uthurry C, Varela F, Colomo B, Suárez-Lepe JA, Lombardero J, García del Hierro JR (2006) Ethyl carbamate production by selected yeasts and lactic acid bacteria in red wine. Food Chem 94:262-270

43. Lonvaud-Funel A (2001) Biogenic amines in wines: role of lactic acid bacteria. FEMS Microbiol Lett 199:9-13

44. Alcaide-Hidalgo JM, Moreno-Arribas MV, Martín-Álvarez PJ, Polo MC (2007) Influence of malolactic fermentation, postfermentative treatments and ageing with lees on nitrogen compounds of red wines. Food Chem 103:572-581

45. Hidalgo J (2003) Tratado de Enología. Mundi-Prensa, Madrid, pp 506-507

46. OIV (2012) Compendium of international methods of analysis-OIV Maximum acceptable limits of various substances contained in wine. (MA-C1-01).www.oiv.int/oiv/files/OIV-MA-C1-01._EN.pdf

47. Rapp A (1993) Foreign and undesirable flavours in wine. TEC \& DOC Lavoisier, Paris 